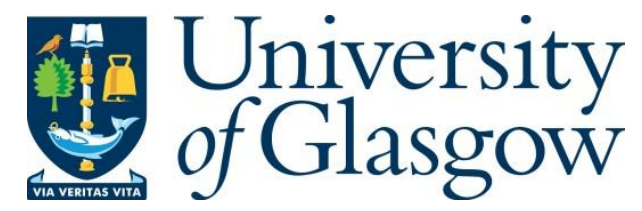

Close, C., Gherghina, S. and Sierens, V. (2018) Prompting legislative agreement and loyalty: what role for intra-party democracy?

Parliamentary Affairs, 72(2), pp. 387-405. (doi:10.1093/pa/gsx075)

This is the author's final accepted version.

There may be differences between this version and the published version. You are advised to consult the publisher's version if you wish to cite from it.

http://eprints.gla.ac.uk/157929/

Deposited on: 26 February 2018

Enlighten - Research publications by members of the University of Glasgow http://eprints.gla.ac.uk 


\title{
Prompting Legislative Agreement and Loyalty: What Role for Intra-Party Democracy?
}

Caroline Close (Department of Political Science, Universite Libre de Bruxelles)

Sergiu Gherghina (Department of Politics, University of Glasgow)

Vivien Siriens (Department of Political Science, Universite Libre de Bruxelles)

\begin{abstract}
Existing research often suggests that a greater degree of internal democracy within parties could weaken party unity. This article tests this assumption and analyses the relationship between degrees of intra-party democracy (IPD) and legislators' attitudes towards party unity. The article uses data collected in the framework of the PartiRep Comparative MP Survey; and of the Political Party Database (PPDB). The study includes 796 parliamentarians in 45 parties, elected in 14 European national assemblies. The findings indicate that the legislators from more democratic party organizations tend to report more frequent disagreement and to assert their own opinions against the one of their parties.
\end{abstract}

Keywords: intra-party democracy, party unity, legislative behaviour, disagreement.

\section{Introduction}

Party unity is a crucial aspect of parliamentary systems that varies across time, parties and countries. Scholars have investigated what shapes this degree of unity at different levels of the polity (Bowler et al. 1999; Depauw \& Martin 2009; Kam 2009; Sieberer 2006; van Vonno et al. 2014) with particular attention being dedicated to the 'party in public office', as one of prominent faces of the party (Katz and Mair, 1993). Research focusing on party-level factors revealed the impact of party size, government status, parliamentary party groups' norms and rules of functioning, the role of committee organization and of division of labour, and candidate selection rules on party unity (Andeweg \& Thomassen 2011; Depauw 2003; Hazan \& Rahat 2006; Patzelt 2003). These findings indicate that general aspects of party organization may influence the behaviour of legislators. In particular, one of the strongest predictors can be the level of intra-party democracy (IPD). Earlier research referred to its explanatory potential and 
conceptualized it mostly as inclusive or decentralized candidate selection procedures. However, although previous studies indicate that IPD means much more than candidate selection (Cross and Katz, 2013; Rahat and Shapira, 2017), little attention has been paid to revealing how IPD in its complex form may shape legislative behaviour.

This article seeks to address this gap in the literature and investigates the extent to which IPD influences party unity, measured as disagreement and loyalty between parliamentarians and their parties. In doing so, the analysis uses two comparative datasets on party organization and legislative behaviour: one to build a comprehensive index of IPD with data collected in the framework of the Political Party Database (PPDB) project (Scarrow et al. 2017) and another to capture MPs' self-reported frequency of (dis)agreement and loyalty through data collected in the frame of the PartiRep Comparative MP Survey (Deschouwer \& Depauw 2014). The analysis includes 796 parliamentarians in 45 parties, elected in 14 European national assemblies. Our central argument is that IPD increases the number of principals, which can have diverging preferences and interests. Consequently, legislators belonging to more democratic parties may thus be more likely to face and report disagreement. Moreover, IPD may cultivate a candidate-centred approach in which the inclusiveness of people in deciding who the next legislator will be is likely to result in lower loyalty towards the party.

We bring two contributions to the literature. First, we propose a complex theoretical model that could link IPD to party unity beyond the single issue of candidate selection. This model is not contextual or country specific and thus can be used by further research. Second, we assess the degree of party unity independently from voting behaviour and disciplinary effects and we use attitudinal data, i.e. what the MPs think rather than what they do. In doing 
so, we challenge the 'black box' of parliamentary parties and examine what usually remains hidden. We differentiate between two dimensions: party agreement, which is defined as 'the extent to which co-partisans agree with one another' (van Vonno et al. 2014); and party loyalty, which derives from the legislators' internalization of the norms of party unity and solidarity.

The remainder of this article is structured as follows. The first section reviews the relevant literature and formulates two expectations about the effects of IPD on legislative agreement and loyalty. Next, we describe the data and method used. The third section presents and interprets the main findings, while the conclusions reflect on the broader implications of this study.

\section{IPD and legislative agreement and loyalty}

We conceive intra-party democracy as a complex concept that includes the degree of inclusiveness of party personnel (candidate and leader) selection and organizational structure. Our central argument posits that IPD decreases the likelihood of parliamentarians' agreement and loyalty towards their party. More specifically, we expect these attitudes to be shaped by the inclusiveness and decentralization of how they and the party leaders are selected and by a more democratic party organization that promotes a participatory culture. We build on findings from earlier research that revealed how legislators who can establish ties with voters and local constituencies are able to display individualistic behaviour in parliament (Tavits, 2009).

Within the legislative field, scholars have intensely investigated the impact of candidate selection rules on parliamentary party unity (Hix 2004; Depauw \& Martin 2009; Rombi \& Seddone 2017; Sieberer 2006). Candidate selection works both as an individualizing (from MPs' 
perspective) and as a disciplinary tool (from parties' perspective). More inclusive and decentralized selectorates would increase intra-party competition for (re)nomination and as a consequence would pressure candidates to distinguish themselves from co-partisans and to cultivate their personal reputation instead of their party's reputation (Carey \& Shugart 1995; Hazan \& Rahat 2015; Sieberer 2006). By contrast, where the re-selection of MPs is more dependent on the choice of a smaller agency or a more exclusive committee, often composed by the main party leaders, MPs would adopt more party-centred behaviours (Gherghina, 2014). When selection is controlled by the leadership, sticking to the party line would constitute a rewarding strategy for MPs seeking re-selection; the party leadership nominating more 'loyal' individuals (Sieberer 2006). More centralized procedures can also be used as 'whipping resources' (Ceron 2014; 2015) by the party leader to enforce compliance with the party's decisions. Centralized candidate selection produces more party-delegates than decentralized procedures (Esaiasson 2000; Önnudóttir 2016; Strøm 2012). In case of conflict between their voters' or their own position and that of their party, the MPs selected through centralized process would be more likely to state that they should follow their party's position, what in turn often translates into voting unity. By contrast, more decentralized candidate selection processes may result in elected representatives feeling caught between being accountable to their localities or to their party, sometimes resulting in MPs defending local positions instead of the central party's position when the interests of their constituency is threatened by the party's policy position.

Another rationale behind this relationship states that more inclusive or decentralized candidate selection methods would expand the diversity of interests and preferences that are 
expressed during intra-party decision-making processes (Hazan \& Rahat 2015), and increase the risk of conflict between the principals (Carey 2007) to which (elected) candidates need to be accountable. MPs selected through inclusive processes show responsiveness to the preferences and interests of their selectorates (delegates, members or supporters). The latter might have quite disperse and heterogeneous positions that could diverge from those of the party leader and voters (May 1973; van Holsteyn \& Andeweg 2010). Consequently, a tension may arise for individual representatives between being accountable to their party members or supporters, who decide MPs' re-selection and have more radical views, and that of the party (leader), and whose preferences are closer to those of the median voter (Gauja, 2005).

The inclusiveness and decentralization of leadership selection may influence in two ways the legislative behaviour. First, when leaders are selected by a broader array of party units within the organization or by many party members, the support of party factions gains relevance (Boucek, 2012, pp. 133-142). MPs belong to different factions in the party and whenever their behaviour against the party line is questioned by the party, the likelihood of punitive actions is lower due to their importance in electing the president. At the same time, since the leadership selection could be a function of faction support, the MPs belonging to factions opposing the new leader may be unhappy with the party's policy directions and thus go against it in parliament (e.g. The case of some Labour MPs and Jeremy Corbyn in the UK)(Bucur, 2017). Second the involvement of more members in the leadership selection process conveys a message of openness to more voices within the party. This openness could be also taken to the legislative arena where MPs belonging to the same party may perceive as welcome their diverging opinions. 
Contemporary political parties are characterized by the idea that power is not located in a single place (Carty, 2004). This model of stratarchical organization entails the existence of a few units enjoying various degrees of autonomy but also interdependence in their particular activities. For example, local units focus on voter mobilisation and member recruitment, while the central units pursue the general integration of the organization and formulate the party policy. In this sense, the central units set the rules according to which the local branches undertake their activities (Carty, 2004). At their turn, local branches are rewarded for their activity and allowed involvement in the intra-party decision-making process on a variety of issues (Gherghina, 2014). This involvement of the local branches creates possibilities for the legislators to move away from party (in central office) control and develop a personal network of supporters that can foster an individualistic behaviour in parliament. The logical mechanism can be summarized as follows. The essence of parliamentarians' work is the representation of their constituency. In this process many become popular among their constituents, they are familiar with voters' needs and policy priorities, while some may have some local roots or local level political experience (Tavits, 2009). A strong localism has two immediate effects: one is that the MPs demonstrate their willingness to respond to problems raised by citizens, send a message of better representation for citizens and thus hope to increase their chances for reelection (Gherghina, 2014); another is the development of an independent profile in which the legislators gain recognition and popularity outside the brand of the party, they cultivate personal contacts and reach out to the electorate and implicitly local party members through other means that the party based. 
Consequently, when local organizations or party members receive an important say in intra-party decisions, the MPs' room for leverage increases. When their behaviour in the legislature goes against the party line, the likelihood to be punished is more limited when they are backed by loyal local organizations and members. Let us take an example that illustrates how this may work in practice. A political party in which the highest executive body (e.g. the executive committee or the national executive, depending on the party) includes several high level officials does not allow for external input about an MP and the legislator's behaviour in parliament is scrutinized only by them. In this case, defection from the party line is likely to be punished. By contrast, a party that allows access to more members and gives them voting rights in the highest executive party will open the floor to more opinions and to input from lower levels where legislators have popularity. In this case, the likelihood of punishment is smaller.

Overall, the literature suggests that greater IPD would result in lower parliamentary party unity, whatever the dimensions observed (homogeneity of preferences, voting loyalty, attitudes towards representation etc.). In line with these arguments, we expect IPD to increase legislators' reported frequency of disagreement $(\mathrm{H} 1)$ and to decrease the legislators' loyalty (H2).

\section{Control variables}

In addition to these main effects, we control for several variables at individual and party level. Individual-level control variables include socio-demographic characteristics (age and gender), MPs' previous parliamentary experience (seniority) and MPs' perceived ideological distance with their party as earlier research showed how they matter (Close \& Núñez, 2017; Cowley \& 
Childs, 2003; Gherghina \& Chiru, 2014; Kam, 2009). In addition, we control for the way each legislator has been elected: party-centred (PR closed or flexible list), intermediate (majoritarian or plurality single-member district), or candidate-centred (PR open list) or system (Mitchell, 2000). The greater the candidate-centeredness of the system, the greater the incentives for individual legislators to cultivate a personal rather than a party vote, and thus to deviate from the party (Carey \& Shugart, 1995; Depauw \& Martin, 2009). At the party level, the models control for party size (\% of seats), period in government and party family. Party families may develop specific intra-party democratic models that reflect their core ideology and origins (Close 2016; Gauja 2013; Poguntke et al. 2016). Previous analyses have included a contextual variable grasping the current (at the time of the survey) position of the party in government or in opposition. Being in government might increase the pressure put on MPs to reach unity (Carey 2007; Stecker 2013); but at the same time might increase the risk of disagreement, as being in a governing coalition can lead parties to adopt positions that contradict the original party manifesto. However, preliminary analyses did not find any significant effect, neither on agreement nor on loyalty.

\section{Data and method}

To test these hypotheses, we combine two cross-country datasets. First, the PartiRep Comparative MP Survey database comprises an attitudinal survey carried out among national and regional legislators in 15 European democracies and other macro-level and meso-level variables (mostly linked to the state structure, electoral system, legislative organization and activity, etc.). MPs were invited to respond either through an online web-survey (46.8\%), print 
questionnaires (33.7\%), face-to-face interviews $(18.7 \%)$ or by telephone $(0.8 \%)$. The data was collected between spring 2009 and winter 2012, with an average response rate of 19.5\%, although this rate varies quite a lot from one parliament to another. Despite these varying response rates, the sample remains representative of the population (Deschouwer et al. 2014) ${ }^{1}$. Our study includes only the MPs elected in national parliaments. For the purpose of the analysis, we excluded respondents who sit as independent in the parliament. We also removed the parties which included less than six respondents in order to allow for enough intra-party variation in the responses provided by each party's MPs. The final database includes 796 individuals from 45 parties elected in 14 national assemblies (lower chamber). Second, the Political Party Database (PPDB) is used to measure intra-party democracy. The PPDB project is a cross-national project examining various aspects of intra-party structure and practices: party membership, selection of party personnel, leadership autonomy, links with collateral organization etc. The project focuses mostly on party official statutes and rules, and less on informal processes, what facilitates data collection, replication and cross-national comparison. The first round of data collection includes information (over 300 variables) on 122 parties in 19 countries during the 2010-2014 period (Poguntke et al. 2016). The selected parties are mostly those elected in the lower house of the national parliaments.

The analysis tests the hypotheses at the individual level through logistic regression models, given the dichotomous nature of the dependent variables (see below). The models control for the effect of oft-cited factors of parliamentary party unity, and given the hierarchical

\footnotetext{
${ }^{1}$ Using the Duncan index of dissimilarity, Deschouwer et al. (2014) have noticed that, as far as party composition is concerned, some parties are slightly underrepresented, while others are slightly overrepresented. The models presented in the analysis have been replicated by applying a party weight. The findings were highly similar.
} 
structure of the data (MPs in parties, parties in countries), multilevel modelling is applied. Multilevel regression fits particularly well our theoretical framework and the nested structure of our data. We use 'random intercept models' that allow to capture systematic between-party and between-country differences, while other effects are assumed to be constant (Stegmueller $2013)^{2}$

\section{Variable operationalization}

For party agreement (DV1), we use a Likert type question that measures the MPs' self-reported frequency of disagreement with their party. ${ }^{3}$ This variable has been dichotomized (whether the MP disagrees more often = 'about once a month' or 'about every three months' or whether the MP does it less frequently = 'about once a year' or '(almost) never') to maximize comparability across parties from different countries given the unequal frequency of sessions across parliaments. This would also facilitate comparisons with the second dependent variable, party loyalty, which is dichotomous. Amongst the 796 parliamentarians, data is missing on that variable for 14 individuals. Amongst the remaining 782 individuals, $61.5 \%$ 'rarely disagree' ${ }^{4}(1=$ agreement), while $38.5 \%$ 'often disagree' ${ }^{5}(0=$ disagreement). For party loyalty (DV2) a question ${ }^{6}$ enables to grasp the extent to which the MPs consider that they should remain loyal to their party (i.e. MP should vote according to his/her party's opinion, coded as 1) or not (MP

\footnotetext{
${ }^{2}$ These models do not assume changes in the slope of the pooled regression but only varying intercept according to the clustering variables.

3 'How often, in the past year, would you say you have found yourself in the position that your party had one opinion on a vote in Parliament, and you personally had a different position?'

${ }^{4} 27.2 \%$ of the MPs said they (almost) never disagreed, $33.2 \%$ said they disagreed about once a year.

${ }^{5} 10.1 \%$ of the MPs said they disagreed about once a month, $29.5 \%$ said they disagreed about once every three months.

6 'And how should, in your opinion, a Member of Parliament vote in the situation that his/her party has one opinion on a vote in Parliament, and he/she personally has another?'.
} 
should vote according to his/her own opinion, coded a 0), in case of a disagreement with their party. Data is missing for 51 MPs (6.5\%), with missing values equally distributed across the sample. Among the remaining MPs, $60 \%$ say they would follow the party line (loyalty), while $40 \%$ consider they should follow their own opinion. While agreement and loyalty correlate weakly (coefficient value 0.11 , significant at 0.01 level), the two are separate dimensions of party unity: ideological and social-psychological. The analysis reveals the extent to which intraparty democracy affects distinctly these two dimensions.

To measure IPD we rely on a simplified version of Poguntke et al.'s (2016, p. 17) 'assembly-based IPD' index, which 'measures the inclusiveness of party decision-making based on discussions within party bodies and assemblies, including assemblies of all members'. From that index we use data only on personnel selection and organizational structure. This is mainly due to data availability: data regarding who has a formal input and a final say in the writing of the manifesto is missing for 12 of the 45 parties included in our dataset. We also simplify the measurement for each component, by including fewer variables. These simplified measurements correlate much with the more complex ones computed by Poguntke et al. (correlation coefficients varying between 0.90 and 0.95 ).

We operationalize our IPD index, on the basis of the two components 'selection of party personnel' and 'organizational structure'. Similarly to Poguntke et al. (2016), we have coded variable items 'as 0.00 or 0.25 if they indicate that a given party has no or a modest level of inclusiveness on this specific aspect of IPD' (Poguntke et al. 2016) (e.g. the final decision for selecting candidates rests in the hands of the party leader or national executive body); 0.50 for a medium level of inclusiveness (e.g. the PPG having the last word), and 0.75 and 1.00 for high 
levels of inclusiveness (e.g. delegates at Congress or all party members). The final IPD index is normally distributed, while the IPD personnel and structure significantly correlate (Pearson coefficient $=0.39$, significant at the 0.01 level).

\section{Table 1 about here}

Regarding the control variables, seniority is measured as the number of years since the MP's first election to the national parliament. Ideological distance is measure as the absolute difference between the MP's placement on a 0-10 left-right scale and the position s/he attributes to her/his party. For the way legislators got elected, party-centred is used as the reference category, as it is the most frequent category. Time in government is measured as the percentage of time a party has been part of the national government between 1975 and $2012^{7}$. Party families were classified in two steps. First, the PartiRep team coded party family on the basis of country experts' judgment. Second, we slightly modified this classification on the basis of the literature on party families, which discusses their existence and coherence along three criteria: origin, ideology and (to a lesser extent) transnational federations (Mair \& Mudde 1998). Seven party families are identified (see the list of parties in Supplementary table S1): radical left (3 parties), green (2), social-democrats (14), liberals (9), Christian-democrats (7), conservatives (12) and radical right (3). Social-democratic parties are used as the reference category, given that it is the most frequent category in the dataset.

\footnotetext{
7 Due to the important changes that occurred in the Italian party system in 1993, time in government of Italian parties is computed for the period 1993-2012. Time in government for the Belgian parties is computed after the split of each of the parties along the linguistic divide (1975).
} 


\section{Analysis and findings}

We present below the hierarchical logistic regression models examining the effect of IPD on legislators' self-reported agreement and loyalty. Four models are estimated for each dimension. Models 1 and 5 include IPD as the sole predictor, models 2 and 6 add individual and party-level controls $^{8}$ except for the way legislators got elected, which is included in models 3 and 7 , and party family, which is added in models 4 and $8 .^{9}$

Models 1 and 2 reveal a negative and significant effect of IPD on MPs' likelihood to report agreement with their party: legislators belonging to more internally democratic parties are more likely to express their disagreement ( $\mathrm{H} 1$ confirmed). This higher frequency of disagreement can result from the fact that more democratic candidate selection procedures increase the risk of conflict between legislators' principals, which might have diverging preferences. It can also stem from the fact that a greater degree of IPD in intra-party decisionmaking processes in general creates an environment in which the expression of diverging opinions is more welcome. In that vein, Cordero and Coller's (2014) study of Spanish parliamentary parties shows that MPs who perceive their selection to be inclusive and decentralized tend to perceive that the building of intra-party position (before the floor is taken) consists in a deliberative process, whereas those who perceive their selection to be centralized and exclusive also perceive that decisions are imposed through a top-down, disciplinary process.

\footnotetext{
${ }^{8}$ A previous version of the paper controlled for the impact of country-level factors (e.g. multilevel or unitary structure of the state), but these were not relevant and did not alter the results.

${ }^{9}$ To ease the interpretation of parameter estimates, most independent variables were centralized around their mean as recommended by Enders \& Tofighi (2007). Categorical variables such as sex, electoral system or party family were not centralized. IPD was not centralized as it is a composite index with a meaningful value of 0 across levels.
} 
In a way, we could say that inclusiveness and decentralization produce a greater 'democratic' culture within the party, in which voice (Hirschman 1970) is more acceptable.

The effect of the electoral system further suggests the importance of 'localism' incentivized by IPD (see above) in shaping legislators' attitudes in parliament: legislators elected in single-member constituencies, and who thus have strong incentives to cultivate a local reputation (Pilet et al., 2012), are less likely to report agreement than those elected in closedlist systems (although the relationship does not reach the significance level). Note that once electoral rules are introduced, the effect of IPD loses strength and statistical significance (model 3). The strength of the IPD effect further decreases when party family is introduced (model 4). Legislators from left-wing party families -and significantly, green parties- are more likely to report frequent disagreement. Interestingly, these families tend to adopt more democratic intra-party decision-making processes (which explains the lower value of the IPD coefficient in model 4), and as such, produce more favourable space for expressing disagreement.

For loyalty, the sign of the coefficient goes in the direction expected by H2: MPs in more internally democratic parties are less likely to report loyal attitudes (models 5 to 7). However, by contrast to agreement, the relationship does not reach the significance level. Besides, once party family is introduced (model 8), the sign of the coefficient becomes positive. The relationship between IPD and legislators' loyalty therefore appears less robust. Nevertheless, the effect of party family suggests an interesting complementary explanation of the impact of intra-party factors on legislators' attitudes towards party unity -but not exactly in the way intended by the usual rational-choice approach and principal-agent framework. Party families adopt specific intra-party democratic models that reflect their core values, and in turn both 
these organizational settings and values may affect the way legislators conceive their role and relate to their party (Close 2016). Model 8 indicates that green legislators are significantly less likely to report loyalty -in a way, they feel more free to state their independence towards their party-, while legislators from radical right parties, which have lower levels of IPD, appear as the most likely to report loyalty. As suggested by Volpi in this volume, a GAL-TAN value effect could also be at play here, with GAL values (promoting individual freedom, self-fulfilment and selfaffirmation, embodied in green and liberal parties for instance) encouraging the expression of individualities within the party.

In order to ease the interpretation of the effect of IPD, figures 1 and 2 plot its marginal effect respectively on legislators' probability to report agreement and loyalty (based on models 3 and 7). The slope of this relationship is clearly steeper in the case of agreement, and the confidence interval is narrower. Legislators in parties with an average IPD of 0.25 have a probability of 0.70 to report agreement, while legislators in parties with an average IPD of 0.75 have a probability of 0.57 to report agreement, thus, a difference of 0.13 ; whereas this difference is only of 0.07 for loyalty (from 0.64 to 0.57 ).

\section{Table 2 about here}

Concerning the model fit, the standard yardstick for multilevel models consists in comparing the likelihood of the different estimated models. The lower the Log-likelihood, the better the model fit. Obviously, this also depends on the number of observations. As these multilevel models are logistic models, we have also computed Tjur's coefficient of discrimination $D^{10}$ to quantify the

\footnotetext{
${ }^{10}$ This coefficient fulfils a similar function as R-square in ordinary least square regression
} 
predictive ability of each regression (Tjur, 2009) ${ }^{11}$. For both dimensions of party unity, the models including solely IPD in the list of predictors have a quite low goodness of fit, suggesting that other variables matter in predicting legislators' agreement and loyalty. Indeed, introducing the control variables improve (although modestly) the explanatory power of the models. The results confirm the effect of oft-cited factors of party unity. As far as agreement is concerned, in line with Bhattacharya and Papageorgiou (this special section), gender matters: women appear less prone to voice their disagreement than men. Unsurprisingly, legislators' perceived left-right distance towards their party increases their propensity to report disagreement. As far as loyalty is concerned, older MPs appear less likely to report loyalty than younger MPs (models 6, 7 and 8), and legislators from larger parties tend to report more loyal attitudes (models 6 and 7).

\section{Figures 1 and 2 about here}

\section{Conclusion}

Existing research has often suggested that greater IPD would decrease parliamentary party unity, but they have been plagued with several limitations. At the empirical level, most studies have exclusively conceived IPD through the degree of inclusiveness or decentralization of candidate selection rules. Besides, party unity has overwhelmingly been measured through voting behavioural data, and to a lesser extent attitudes towards representation have been considered. These limitations imply that we still have a limited understanding of the relationship between a party's degree of IPD and the various dimensions of parliamentary party unity.

\footnotetext{
${ }^{11} \mathrm{AIC}$ and BIC provide a similar information as the log-likelihood but these measures are based 'on the likelihood of the data given a fitted model (the 'likelihood') penalized by the number of estimated parameters of the model' (Nakagawa \& Schielzeth, 2013, p. 134).
} 
This research has attempted to address these issues. First, we have used a comprehensive index of IPD, taking into account both intra-party personnel selection rules and organizational structure. This has allowed grasping the general degree of inclusiveness of intraparty processes. Second, we have examined two pre-floor attitudinal dimensions of unity: legislators' self-reported frequency of agreement, and their reported loyalty in case of disagreement between their opinion and the position of their party on a specific policy. This has helped measuring legislative unity net of disciplinary effect, and permitted to get deeper into the 'black box' of parliamentary parties.

Our findings tend to confirm the widespread assumption that a greater IPD would produce greater legislative disunity, but in attitudinal rather than in behavioural terms. Depending on the degree of inclusiveness of intra-party processes, measured through our index but also grasped through party family, legislators seem more or less willing to report frequent disagreement with their party, and to assert their own opinion in the face of their party. The greater the internal democratic 'culture', the more likely legislators will report frequent disagreement and individualistic attitudes.

However, we must admit that the effects uncovered lack a bit of robustness, especially that between IPD and loyalty. Other limitations pertain to the design and implementation of this type of elite survey (e.g. selection biases, varying response rates, limited $\mathrm{N}$ etc.). Nevertheless, we think this research contributes well to the discussion on the determinants of parliamentary party unity, by providing a new investigation into the relationship between IPD and legislative unity, and by proposing a more sociological understanding of the relationship between intraparty organization and the processes of party unity. 


\section{List of references:}

Andeweg, R.B., Thomassen, J., 2011. Pathways to party unity: Sanctions, loyalty, homogeneity and division of labour in the Dutch parliament. Party Polit. 17, 655-672.

Boucek, F., 2012. Factional Politics: How Dominant Parties Implode or Stabilize. Palgrave Macmillan, London.

Bowler, S., Farrell, D., Katz, R. (Eds.), 1999. Party Discipline and Parliamentary Government. Ohio State University Press, Columbus.

Bucur, C., 2017. Democratisation of Chief Executive Candidate Selection and Party Discipline in Parliamentary Democracies. Presented at the ECPR Joint Sessions of Workshops.

Carey, J.M., 2007. Competing Principals, Political Institutions, and Party Unity in Legislative Voting. Am. J. Polit. Sci. 51, 92-107.

Carey, J.M., Shugart, M.S., 1995. Incentives to cultivate a personal vote: A rank ordering of electoral formulas. Elect. Stud. 14, 417-439.

Carty, R.K., 2004. Parties as Franchise Systems: The Stratarchical Organizational Imperative. Party Polit. 10, 5-24.

Ceron, A., 2015. Brave rebels stay home Assessing the effect of intra-party ideological heterogeneity and party whip on roll-call votes. Party Polit. 21, 246-258.

Ceron, A., 2014. Inter-factional conflicts and government formation Do party leaders sort out ideological heterogeneity? Party Polit.

Close, C., 2016. Parliamentary party loyalty and party family The missing link? Party Polit. [online first].

Close, C., Núñez, L., 2017. Preferences and agreement in legislative parties: testing the causal chain. J. Legis. Stud.

Cordero, G., Coller, X., 2014. Cohesion and Candidate Selection in Parliamentary Groups. Parliam. Aff. 1-24.

Cowley, P., Childs, S., 2003. Too Spineless to Rebel? New Labour's Women MPs. Br. J. Polit. Sci. 33, 345-365.

Cross, W.P., Katz, R.S. (Eds.), 2013. The Challenges of Intra-Party Democracy, Comparative Politics. Oxford University Press, Oxford.

Depauw, S., 2003. Government Party Discipline in Parliamentary Democracies: the Cases of Belgium, France and the United Kingdom in the 1990s. J. Legis. Stud. 9, 130-146.

Depauw, S., Martin, S., 2009. Legislative party discipline and cohesion in comparative perspective., in: Giannetti, D., Benoit, K. (Eds.), Intra-Party Politics and Coalition Goverments. Routledge, London \& New York, pp. 103-120.

Deschouwer, K., Depauw, S. (Eds.), 2014. Representing the People: A Survey Among Members of Statewide and Substate Parliaments, Comparative Politics. Oxford University Press, Oxford, New York.

Deschouwer, K., Depauw, S., André, A., 2014. Representing the people in parliaments, in: Deschouwer, K., Depauw, S. (Eds.), Representing the People. A Survey among Members of Statewide and Substate Parliaments. Oxford University Press, Oxford, pp. 1-18.

Enders, C.K., Tofighi, D., 2007. Centering predictor variables in cross-sectional multilevel models: a new look at an old issue. Psychol. Methods 12, 121-138. 
Esaiasson, P., 2000. How Members of Parliament Define Their Task, in: Esaiasson, P., Heidar, K. (Eds.), Beyond Westminster and Congress: The Nordic Experience. Ohio State University Press, Cleveland, $\mathrm{OH}, \mathrm{pp}$. 51-82.

Gauja, A., 2013. Policy Development and Intra-Party Democracy, in: Cross, W.P., Katz, R.S. (Eds.), The Challenges of Intra-Party Democracy, Comparative Politics. Oxford University Press, Oxford, pp. 116-135.

Gauja, A., 2005. The pitfalls of participatory democracy: A study of the Australian Democrats' GST. Aust. J. Polit. Sci. 40, 71-85.

Gherghina, S., 2014. Party Organization and Electoral Volatility in Central and Eastern Europe: Enhancing Voter Loyalty. Routledge, London.

Gherghina, S., Chiru, M., 2014. Determinants of legislative voting loyalty under different electoral systems: Evidence from Romania. Int. Polit. Sci. Rev. 35, 523-541.

Hazan, R.Y., Rahat, G., 2015. Parties, Politicians, and Parliaments: The Impact of Intra-Party Democracy on Party Unity, in: Johnston, R., Sharman, C. (Eds.), Parties and Party Systems. Structure and Context. University of British Columbia Press, Vancouver, pp. 108-126.

Hazan, R.Y., Rahat, G., 2006. The influence of candidate selection methods on legislatures and legislators: Theoretical propositions, methodological suggestions and empirical evidence. J. Legis. Stud. 12, 366-385.

Hirschman, A.O., 1970. Exit, Voice, and Loyalty: Responses to Decline in Firms, Organizations, and States. Harvard University Press, Cambridge, MA.

Hix, S., 2004. Electoral Institutions and Legislative Behavior: Explaining Voting Defection in the European Parliament. World Polit. 56, 194-223.

Kam, C.J., 2009. Party Discipline and Parliamentary Politics. Cambridge University Press, Cambridge.

Katz, R.S., Mair, P., 1993. The Evolution of Party Organizations in Europe: The Three Faces of Party Organization. Am. Rev. Polit. 14, 593-617.

Mair, P., Mudde, C., 1998. The Party Family and Its Study. Annu. Rev. Polit. Sci. 1, 211-229.

May, J.D., 1973. Opinion Structure of Political Parties: The Special Law of Curvilinear Disparity. Polit. Stud. 21, 135-151.

Mitchell, P., 2000. Voters and their representatives: electoral institutions and delegation in parliamentary democracies. Eur. J. Polit. Res. 37, 335-351.

Nakagawa, S., Schielzeth, H., 2013. A general and simple method for obtaining R2 from generalized linear mixed-effects models. Methods Ecol. Evol. 4, 133-142.

Önnudóttir, E.H., 2016. Political parties and styles of representation. Party Polit. 22, 732-745.

Patzelt, W.J., 2003. Party Cohesion and Party Discipline in German Parliaments. J. Legis. Stud. 9, 102-115.

Pilet, J.-B., Freire, A., Costa, O., 2012. Ballot Structure, District Magnitude and ConstituencyOrientation of MPs in Proportional Representation and Majority Electoral Systems. Representation 48, 359-372.

Poguntke, T., Scarrow, S.E., Webb, P.D., 2016a. Party Rules, Party Resources, and the Politics of Parliamentary Democracies: How Parties Organize in the 21st Century. Party Polit. 22, 661-678. 
Poguntke, T., Scarrow, S.E., Webb, P.D., 2016b. Party Rules, Party Resources, and the Politics of Parliamentary Democracies: How Parties Organize in the 21st Century. Party Polit. 22, 661-678.

Rahat, G., Shapira, A., 2017. An Intra-Party Democracy Index: Theory, Design and A Demonstration. Parliam. Aff. 70, 84-110.

Rombi, S., Seddone, A., 2017. Rebel Rebel. Do Primary Elections Affect Legislators' Behaviour? Insights from Italy. Parliam. Aff. online fir.

Scarrow, S.E., Webb, P.D., Poguntke, T. (Eds.), 2017. Organizing Political Parties: Representation, Participation, and Power, Comparative Politics. Oxford University Press, Oxford, New York.

Sieberer, U., 2006. Party unity in parliamentary democracies: A comparative analysis. J. Legis. Stud. 12, 150-178.

Stecker, C., 2013. How effects on party unity vary across votes. Party Polit. (Online Fi, 1-12.

Stegmueller, D., 2013. How Many Countries for Multilevel Modeling? A Comparison of Frequentist and Bayesian Approaches. Am. J. Polit. Sci. 57, 748-761.

Strøm, K., 2012. Roles as Strategies: Towards a Logic of Legislative Behaviour, in: Blomgren, M., Rozenberg, O. (Eds.), Parliamentary Roles in Modern Legislatures. Routledge, Abingdon, Oxon, pp. 85-100.

Tavits, M., 2009. The Making of Mavericks. Local Loyalties and Party Defection. Comp. Polit. Stud. 42, 793-815.

Tjur, T., 2009. Coefficients of Determination in Logistic Regression Models-A New Proposal: The Coefficient of Discrimination. Am. Stat. 63, 366-372.

van Holsteyn, J.J.M., Andeweg, R.B., 2010. Demoted leaders and exiled candidates: Disentangling party and person in the voter's mind. Elect. Stud., Special Symposium: The 2008 U.S. Presidential Election 29, 628-635. doi:10.1016/j.electstud.2010.06.003

van Vonno, C.M.C., Itzkovitch Malka, R., Depauw, S., Hazan, R.Y., Andeweg, R.B., 2014. Agreement, Loyalty and Discipline: A Sequential Approach to Party Unity, in: Deschouwer, K., Depauw, S. (Eds.), Representing the People. A Survey among Members of Statewide and Substate Parliaments. Oxford University Press, Oxford, pp. 110-136. 
Figure 1. Predicted probabilities: Marginal effect of IPD on legislators' reported agreement (model 3).

Figure 2. Predicted probabilities: Marginal effect of IPD on legislators' reported loyalty (model 7).

Table 1. Composition of IPD index.

\begin{tabular}{|c|c|c|}
\hline 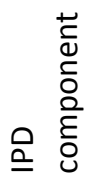 & $\begin{array}{l}\text { Personnel selection inclusiveness } \\
\qquad \text { index }^{12}\end{array}$ & Organizational structure inclusiveness index \\
\hline \multirow{4}{*}{$\begin{array}{l}\frac{\mathscr{U}}{0} \\
\frac{0}{\frac{\pi}{2}} \\
\frac{\pi}{0} \\
0 \\
\frac{0}{0}\end{array}$} & $\begin{array}{l}\text { Who has the final vote in the party } \\
\text { leader selection process? }\end{array}$ & Who is eligible to vote at the party congress? \\
\hline & $\begin{array}{l}\text { Who has the final vote in the } \\
\text { candidate selection process }\end{array}$ & How frequently must a party congress be held ${ }^{13}$ \\
\hline & & $\begin{array}{l}\text { Number of layers between the party congress and the highest } \\
\text { executive body }{ }^{14}\end{array}$ \\
\hline & & $\begin{array}{l}\text { Number of members with voting rights in the party highest } \\
\text { executive body }\end{array}$ \\
\hline \multirow{2}{*}{ 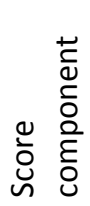 } & $\begin{array}{l}\text { Arithmetic mean of leadership and } \\
\text { candidate selection variables }\end{array}$ & Arithmetic mean of organizational structure variables \\
\hline & \multicolumn{2}{|c|}{ IPD index= Arithmetic mean of the components 'Personnel-selection' and 'Organizational stucture' } \\
\hline
\end{tabular}

Table 2. The effect of intra-party democracy on legislative agreement and loyalty- Multilevel models

\begin{tabular}{|c|c|c|c|c|c|c|c|c|}
\hline & \multicolumn{5}{|c|}{ Agreement } & \multicolumn{3}{|c|}{ Loyalty } \\
\hline & (1) & (2) & (3) & (4) & (5) & (6) & (7) & (8) \\
\hline \multicolumn{9}{|l|}{ Fixed Part } \\
\hline \multirow[t]{2}{*}{ IPD } & $-1.116^{*}$ & $-1.058^{*}$ & -0.721 & -0.575 & -0.886 & -0.585 & -0.499 & 0.452 \\
\hline & $(0.585)$ & $(0.592)$ & $(0.600)$ & $(0.625)$ & $(0.943)$ & $(0.973)$ & (1.006) & $(0.988)$ \\
\hline \multirow[t]{2}{*}{ Age } & & 0.003 & 0.003 & 0.004 & & $-0.019^{*}$ & $-0.020^{* *}$ & $-0.020^{* *}$ \\
\hline & & (0.009) & (0.009) & (0.009) & & $(0.010)$ & $(0.010)$ & $(0.010)$ \\
\hline Sex & & $0.521^{* * *}$ & $0.509^{* * *}$ & $0.593^{* * *}$ & & 0.089 & 0.075 & 0.093 \\
\hline \multicolumn{9}{|c|}{$\begin{array}{l}13 \text { Coding: More often than once per year }=1.00 \text {, Once per year }=0.75 ; \text { Between } 1 \text { to } 3 \text { years }=0.50 ; \text { Every } 3 \\
\text { years }=0.25 ; \text { Every } 4-5 \text { years }=0.00 \text {. } \\
{ }^{14} \text { Coding : } 1=1.00 ; 2=0.50 ; 3=0.00\end{array}$} \\
\hline $\begin{array}{l}{ }^{15} \text { Coding : Less than } 10=0.00 \text {; Bet } \\
\text { More than } 60=1.00\end{array}$ & ween 10 & and $19=0.2$ & 25 ; Betw & en 20 ar & $39=0.50$ & ; Betweer & n 40 and & $59=0.7$ \\
\hline
\end{tabular}




\begin{tabular}{|c|c|c|c|c|c|c|c|c|}
\hline & & $(0.183)$ & $(0.186)$ & $(0.188)$ & & (0.198) & (0.199) & $(0.200)$ \\
\hline \multirow[t]{2}{*}{ Seniority } & & -0.002 & -0.002 & -0.001 & & 0.002 & 0.002 & 0.001 \\
\hline & & $(0.013)$ & $(0.013)$ & $(0.013)$ & & $(0.014)$ & $(0.014)$ & $(0.014)$ \\
\hline \multirow[t]{2}{*}{ LR Distance } & & $-0.325^{* * *}$ & $-0.328^{* * *}$ & $-0.330^{* * *}$ & & -0.090 & -0.093 & -0.098 \\
\hline & & $(0.085)$ & $(0.085)$ & $(0.085)$ & & $(0.088)$ & (0.088) & (0.089) \\
\hline \multirow[t]{2}{*}{ Party Size } & & 0.011 & 0.014 & 0.001 & & $0.027^{*}$ & $0.029^{*}$ & 0.017 \\
\hline & & $(0.014)$ & $(0.015)$ & $(0.013)$ & & $(0.017)$ & $(0.017)$ & $(0.015)$ \\
\hline \multirow[t]{2}{*}{ Time in Government } & & -0.002 & -0.003 & -0.007 & & 0.004 & 0.004 & 0.004 \\
\hline & & $(0.005)$ & $(0.005)$ & $(0.006)$ & & $(0.006)$ & $(0.006)$ & $(0.007)$ \\
\hline \multirow[t]{2}{*}{ Intermediate electoral system } & & & -0.209 & -0.298 & & & -0.236 & -0.368 \\
\hline & & & $(0.221)$ & $(0.231)$ & & & $(0.320)$ & $(0.308)$ \\
\hline \multirow[t]{2}{*}{ Candidate-centred electoral system } & & & 0.591 & 0.398 & & & 0.123 & 0.290 \\
\hline & & & $(0.397)$ & (0.429) & & & $(0.791)$ & $(0.725)$ \\
\hline \multirow[t]{2}{*}{ Radical left } & & & & -0.450 & & & & -0.530 \\
\hline & & & & $(0.446)$ & & & & $(0.601)$ \\
\hline \multirow[t]{2}{*}{ Green } & & & & $-1.388^{* *}$ & & & & $-1.840^{* *}$ \\
\hline & & & & $(0.539)$ & & & & $(0.776)$ \\
\hline \multirow[t]{2}{*}{ Liberal } & & & & 0.122 & & & & -0.445 \\
\hline & & & & $(0.315)$ & & & & $(0.378)$ \\
\hline \multirow[t]{2}{*}{ Christian-democrats } & & & & 0.403 & & & & 0.127 \\
\hline & & & & $(0.289)$ & & & & (0.369) \\
\hline \multirow[t]{2}{*}{ Conservatives } & & & & 0.167 & & & & -0.252 \\
\hline & & & & $(0.228)$ & & & & $(0.277)$ \\
\hline \multirow[t]{2}{*}{ Radical right } & & & & 0.309 & & & & 1.158 \\
\hline & & & & $(0.587)$ & & & & $(0.765)$ \\
\hline \multirow[t]{2}{*}{ Constant } & $1.106^{* * *}$ & $0.941^{* * *}$ & $0.741^{*}$ & 0.601 & 0.957 & 0.727 & 0.718 & 0.295 \\
\hline & $(0.358)$ & $(0.358)$ & $(0.379)$ & $(0.415)$ & $(0.593)$ & $(0.610)$ & $(0.662)$ & $(0.665)$ \\
\hline \multicolumn{9}{|l|}{ Random Part } \\
\hline$\tau 00$, Party & 0.033 & 0.091 & 0.112 & 0.000 & 0.249 & 0.214 & 0.229 & 0.07 \\
\hline$\tau 00$, Country & 0.109 & 0.050 & 0.012 & 0.077 & 0.683 & 0.791 & 0.705 & 0.569 \\
\hline Observations & 781 & 722 & 722 & 722 & 739 & 739 & 689 & 689 \\
\hline N Party & 45 & 45 & 45 & 45 & 45 & 45 & 45 & 45 \\
\hline N Country & 14 & 14 & 14 & 14 & 14 & 14 & 14 & 14 \\
\hline Tjur's D & 0.042 & .071 & 0.074 & 0.076 & 0.143 & 0.172 & 0.172 & 0.172 \\
\hline Log Likelihood & -514.355 & -465.630 & -463.913 & -459.082 & -466.164 & -426.436 & -426.141 & -420.081 \\
\hline Akaike Inf. Crit. & $1,036.710$ & 951.259 & 951.826 & 954.164 & 940.329 & 872.872 & 876.283 & 876.162 \\
\hline Bayesian Inf. Crit. & $1,055.353$ & 3997.080 & $1,006.811$ & $1,036.641$ & 958.750 & 918.224 & 930.706 & 957.796 \\
\hline
\end{tabular}

Note: ${ }^{*} p<0.1 ;{ }^{* *} p<0.05 ; * * * p<0.01$ 
Supplementary Table S1: List of parties included in the analysis

\begin{tabular}{|c|c|c|c|}
\hline Country ( $\&$ year of election) & Parties & Party family & IPD \\
\hline \multirow[t]{4}{*}{ Austria (2008) } & FPÖ & $\mathrm{RR}$ & .25 \\
\hline & Grüne & GRE & .54 \\
\hline & ÖVP & $\mathrm{CHD}$ & .33 \\
\hline & SPÖ & SD & .29 \\
\hline \multirow[t]{7}{*}{ Belgium (2007) } & $\mathrm{CDH}$ & $\mathrm{CHD}$ & .72 \\
\hline & $C D \& V$ & $\mathrm{CHD}$ & .81 \\
\hline & MR & LIB & .50 \\
\hline & Open VLD & LIB & .91 \\
\hline & PS & SD & .72 \\
\hline & SP.A & SD & .67 \\
\hline & Vlaams Belang & $\mathrm{RR}$ & .13 \\
\hline \multirow[t]{2}{*}{ France (2007) } & PS & SD & .38 \\
\hline & UMP & CON & .34 \\
\hline \multirow[t]{6}{*}{ Germany (2009) } & CDU & $\mathrm{CHD}$ & .66 \\
\hline & CSU & $\mathrm{CHD}$ & .67 \\
\hline & Bündnis 90/Die Grünen & GRE & .66 \\
\hline & Die Linke & $\mathrm{RL}$ & .69 \\
\hline & FDP & LIB & .69 \\
\hline & SPD & SD & .59 \\
\hline \multirow[t]{2}{*}{ Hungary (2006) } & Fidesz & CON & .50 \\
\hline & MSZP & SD & .66 \\
\hline \multirow[t]{3}{*}{ Ireland (2007) } & Fianna Fáil & CON & .54 \\
\hline & Fine Gael & CON & .50 \\
\hline & Labour & SD & .72 \\
\hline Israel (2009) & Kadima & LIB & .75 \\
\hline \multirow[t]{2}{*}{ Italy (2008) } & Partito Democratico & SD & .88 \\
\hline & Popolo della Libertà & CON & .81 \\
\hline \multirow[t]{4}{*}{ Netherlands (2006) } & CDA & CHD & .78 \\
\hline & PvdA & SD & .84 \\
\hline & SP & $\mathrm{RL}$ & .63 \\
\hline & VVD & LIB & .47 \\
\hline \multirow[t]{4}{*}{ Norway (2005) } & Arbeiderpartiet & SD & .52 \\
\hline & Fremskrittpartiet & $\mathrm{RR}$ & .59 \\
\hline & Høyre & CON & .56 \\
\hline & Socialistisk Venstreparti & $\mathrm{RL}$ & .59 \\
\hline \multirow[t]{2}{*}{ Poland (2007) } & PiS & CON & .25 \\
\hline & $\mathrm{PO}$ & CON & .13 \\
\hline \multirow[t]{3}{*}{ Portugal (2009) } & CDS/PP & CON & .53 \\
\hline & PSD & LIB & .53 \\
\hline & PS & SD & .53 \\
\hline \multirow[t]{2}{*}{ Spain (2008) } & PP & CON & .47 \\
\hline & PSOE & SD & .44 \\
\hline \multirow[t]{3}{*}{ United Kingdom (2010) } & Conservative Party & CON & .72 \\
\hline & Labour Party & SD & .78 \\
\hline & Liberal Democrats & LIB & .88 \\
\hline
\end{tabular}

